\title{
A Contested Muslim Identity in Kazakhstan: Between Liberal Islam and the Hanafi Project
}

\author{
Nodar Karimov \\ Oxford Centre for Islamic Studies, Astana, Kazakhstan
}

\begin{abstract}
The liberal pattern in Islam displayed itself at different points in the history of Kazakhstan through quasi state models of political organization, governance networks, multiethnic and multireligious societies, individual freedoms, and syncretic essence of Islam in the local culture. This paper examines the role of liberal pattern in the evolution of Islam in Kazakhstan based on historical and antropological analysis to call into question the state's ongoing efforts to plant the authoritarian interpretation of Islam epitomized in the so-called Hanafi project. The notion of the Hanafi project is offered as the antithesis to classical Islamic Hanafi School, which is manipulated by the state to mask the imposition of the secular national policy in the religious domain.
\end{abstract}

Keywords: Islam, Muslim identity, liberal pattern, Hanafi project, social contract, governance networks, multiculturalism

\section{Introduction (Goal, Relevance, and Research Questions)}

One of the defining characteristics of Islam in Central Asia is its diversity that for centuries has been intertwining with the interests of local communities and interacting with national cultures. Historically, one can trace here the existence of a great variety of Islamic forms ranging from Sunni and Shiite movements (Murji'ah, Isma'ilism, and Mubayida), Sunni theological schools (Maturidism, Ash'arism, and Karramiyyah), Sunni schools of jurisprudence (Hanafism and Shafiism) to Sufi orders (Naqshbandiya, Yasaviya, Kubraviya, Ishkiya, Qadiriya, and Afaqiyya). Islam existed through these multiple forms concurrently interacting with local national cultures which resulted in the emergence of a unique Central Asian form of Islam still an integral part of the global Islamic civilization.

This rich mosaic has determined the liberal ${ }^{1}$ nature of Islam in Kazakhstan, which occupies vital place in the nomadic steppes of Central Asia. Here, the liberal pattern displayed itself at different points in history through quasi state models of political organization, community/governance networks, multiethnic and multireligious societies, individual freedoms, free trade system, and syncretic essence of Islam in the local culture. Analyzing Kazakh hordes of the 16th and 17th centuries, Olcott (1987) defined them as "federations or unions of self-governed tribes" that "bear the mark of military democracy rather than a feudal society". Beyond this tribes and clans, acted as strong institutions of nomadic civil society effectively limits the power of Khan

\footnotetext{
Nodar Karimov, Ph.D., Chevening Visiting Fellow, Oxford Centre for Islamic Studies.

1 Favourable to or respectful of individual rights and freedoms (Oxford Dictionaries: https://en.oxforddictionaries.com/definition/liberal)
} 
and protects ordinary folks from the tyranny of the authorities. ${ }^{2}$ Levshin (1832) described elections and intensive debates over the nomination of khan as one of the most important ceremonies in the political life of the Kazakh people, which exemplify traditions of representative democracy.

Contemporary Kazakhstan has embraced the path that does not have much in common with this legacy of freethinking of the past. At the expense of heterogeneity and inclusion, Islam in the country has been reduced to an element of the secular nationalist ${ }^{3}$ doctrine with practicing Muslims facing growing deprivation in the society. Sultangalieva characterized this as "division of Islam into 'good' traditional and 'bad' non-traditional" and believed that "official or semi-official designation of certain forms of Islam leads to politicization of religion" . The state continues to shed the cultural and administrative legacy of the Soviet rule and limits discussion on Islam within the paradigm we have come define as the Hanafi Project-a hybrid ideology of a secular type built on an agglomerate of the state national policies, local ethnic traditions, and certain elements of the classical Islamic Hanafi School disguised as the only historically predetermined local authentic form of the Sunni Islam. We offer the notion of the Hanafi Project as the antithesis to classical Islamic Hanafi School, which is manipulated by the state to mask the imposition of the secular national policy in the religious domain. The principles of the Hanafi Project has been laid out in the state law "On religious activity and religious associations" where they were proclaimed a basis of the national culture to replace all other forms of Islamic identity. The law did not only reduce drastically the number of recognized religions, but is also closely intertwined with the extremism law, which gives the government discretion to designate any group as an extremist organization, ban its activities, criminalize its members, and seize its property (Hays, 2016).

While the classical Hanafi School is known for tolerating differences within Muslim communities ${ }^{5}$, the Hanafi Project ultimately encourages attacks on multiculturalism. As part of the project, the majority of country's mosques, including those of national minorities, were put under the control of the Spiritual Administration of Muslims. This puppet semi-government organization that tends to see "danger in any religious groups that hold alternative views, even if they are peaceful and do not pursue radical aims" (Amire, 2014) now holds the exclusive rights to appoint imams. Only in 2012, 2,228 out of the 2,756 mosques of the country had been re-registered as branches of Spiritual Administration (Baigarin, 2011).

Whereas the classical Hanafi Schools have always been considered among the most flexible and liberal in Islamic law in the areas of individual freedoms and criminal law ${ }^{6}$, the Hanafi Project comes together with state securitization of religion. The role of security forces in designing and implementing religious policies has sharply increased which echoed in growing interference in private lives of the non-mainstream religious groups and mundane inequality at the community level. One of the major religious groups of the country, Sufis and moderate Salafis (Madkhalis) are perceived as political opposition to the secular state facing grassroots xenophobia directed from above. In 2011, following a closed trial, nine leaders of the Kazakh Sufi community,

\footnotetext{
2 Sabitov, Z. "Steppe democracy" and the "Elections in the great steppe", Vlast online magazine: https://vlast.kz/avtory/15340-stepnaa-demokratia-i-vybory-v-velikoj-stepi.html

3 Nationalism-ideology based on the premise that the individual's loyalty and devotion to the nation-state surpass other individual or group interests. Nationalism implies the identification of the state or nation with the people and desirability of determining the extent of the state according to ethnographic principles (Encyclopaedia Britannica: https://www.britannica.com/topic/nationalism)

4 V Kazakhstane poyavilsya fenomen "novykh musul" man (In Kazakhstan, there appeared a phenomenon of "New Muslims"), Tengrinews, 2011: http://tengrinews.kz/kazakhstan_news/v-kazahstane-poyavilsya-fenomen-novyih-musulman-202012/

5 “Category: Madhabs", Eureka Encyclopedia: http://www.eurekaencyclopedia.com/index.php/Category:Madhabs ${ }^{6}$ Ibid.
} 
including the prominent Sheikh Ismatulla, was sentenced to long-term imprisonment. The lawyers defend the Sufi group spoke of the politically motivated, hasty, and unreasonably harsh charges (Toguzbayev, 2011). According to official data, in 2015, more than 500 people were jailed on charges related to engaging in religious extremist and terrorist activities. Most of those convicted in 2008-2014 received their sentences for non-violent crimes: participation in the activities of a terrorist group (56\%) or advocacy of terrorism (21\%). Only about $20 \%$ of the convicts were arrested on charges of direct involvement or the organization of a terrorist act (Beissembayev, 2016). Kazakhstan banned wearing hijab in education institutions across the country (Radio Free Europe/Free Liberty, 2016) with children from religious minority groups reportedly not allowed to take classes at school (Urnaliyev, 2017).

The research examines the role of liberal pattern in the evolution of Islam in Kazakhstan based on historical and antropological analysis to call into question the state's ongoing efforts to plant the authoritarian interpretation of Islam epitomized in the so-called Hanafi Project. We will look into patterns of Islam which shares parallel concerns with Western liberalism to understand how they played out in the state dynamics and group consciousness, and how they shaped the contemporary identity of Muslims in the country. This captures vital aspects of the everyday life: religious practices, political organization, inter-communal relationship and socialization, law and conflict resolution, and social and cultural norms and values. Focusing on religious diversity, the research evaluates how the balance between various Islamic groups has been historically upheld, which seems to have been reversed with the introduction of the Hanafi Project during the first decades of the independence after 1991. We argue that the Islamic identity of the region has been determined by liberal multicultural rather than mono-religious (mono-madhab) trend, which makes groundless the state's argument about historical predestination of a single form of religiosity. Finally, the research suggests that dissemination of liberal and pluralistic interpretations of Islam is the only path to stability and tolerance for Kazakhstan in the current religious and political environment.

\section{Methodology}

Dahl argues that no modern country meets the ideal of democracy, which is a theoretical utopia, but this is not a cause for denying the possibility of democratic rule (Mosca, 1939). It is possible to establish minimum threshold of meaningful democratic achievement through observable conditions that provide an operational definition of democracy (Krouse, 1982). The research attains these observable conditions using Dahl's method of maximization (Dahl, 1956; 1963) and extracts three operationally meaningful characteristics of the liberal democracy in the works of prominent experts on the subject: (1) rule of law; (2) governance networks; and (3) multiculturalism (Forde, 2011; Stanford Encyclopedia of Philosophy, 2016; U.S. History Online Textbook, 2017; Jenkinson, 2004; Fukuyama, 1992). These three characteristics are then segregated into stringen conditions sufficient to maximize attainment of these objectives in the real world: (1) rule of law: limited state, social contract; (2) governance networks: self-governance, political freedom; and (3) multiculturalism: syncretism, cultural, and religious toleration (Krouse, 1982).

To achieve the objectives of the research we also applied the principles of Bourdieu's (1977) "practice theory", which suggests that the foundations of collective identity are in the daily behavior of those who ascribe to that identity (Bourdieu, 1977). Using the "practice theory", we: (1) traced common patterns of Islam and Western liberalism in the history of Kazakhstan and Central Asia; (2) discovered how those patterns played out in the daily practices through state dynamics and group consciousness; (3) analyzed religious life of various 
Muslim communities of the region and highlighted the dynamic ways in which they were interacting in their political and religious practice. The research has its own limitations, as it will not prioritize on exhaustive comparison between the theories of classical Islam and liberal democracy to show to what extent they are compatible.

\section{The Definition of Liberal Islam}

Religious factor became an important trend in the foreign and domestic political agenda of the contemporary states of Central Asia. Ideological revival of Islam requires to rethink accumulated experience of Islamic and human civilizations, the ideas of democracy, social order, social equality, and political freedom through the prism of religious values. The Muslimness of the Central Asian population vary considerably so that Islamic revival, according to Ro'i and Wainer (2009), appears to be much more a development that combines paths towards past and future, mixing different notions of tradition and modernity, less so a clear re-establishment of the Hanafi School of thought, deemed valid by the secular state and its religious policies. The post-communist states of Central Asia also did not remain outside the global democratization processes which in Islamic context imply what Kurzman has called "liberal meta-narratives of Islamic discourse"-a thriving movement of Muslim thinkers towards democracy, separation of church and state, rights of women, rights of minorities, freedom of thought, and the idea of human progress. Although the term "liberal" has negative connotations in many Muslim communities across the globe ${ }^{7}$, Islam is not only theoretically compatible with the principles of liberal democracy.

Debates about "liberal Islam" and compatibility of Islam and democracy are almost as old as the ideology of liberalism itself. From the Aligarh Movement in 19 century British India to the al-Nahda ${ }^{8}$ in the Arab world, Muslims have sought to synthesise Islam and liberalism to advance Islam's civilisational progress and saw no contradiction between Islam and the values of freedom, tolerance, human rights, and the rule of law (Kazmi, 2015). Al-Tahtawi, Abduh, Rida, Ahmed Khan, and Al-Afghani addressed the issue and formed a transnational class of intellectuals, administrators, and reformers that reached its apogee in the 1920s (Mondal, 2003). Khan and Abduh argued about a coincidence between Islamic values and Western liberalism that had been forgotten or obscured. Pointing to the mid-19th century Young Ottomans and their synthesis of Islam and constitutional liberalism, Akyol concludes that "such Western liberal categories as tolerance, individual liberty, and human rights are recognisable in Turkey's Islamic history" (Kazmi, 2015).

In this research, we expand this vision further by adhering to Kurzman's definition of "liberal Islam" as "interpretation of Islam that have a special concern regarding democracy, women's rights, freedom of thought, and promoting human progress". Kurzman (1999) argued that both Muslims and religious piety itself benefit from reforms and a more open society, which parallel liberalism in other cultures and liberal movements in various religious faiths". The liberal approach in Islam has been also stimulated by historic shifts of the past quarter century: The rise of secular higher education in the Islamic world which has broken the monopoly of the seminaries over religious discourse; the growth of international communications which has made educated Muslims more aware of the norms and institutions of the West; and the failure of Islamic regimes to deliver an attractive alternative (Kurzman, 1999).

\footnotetext{
${ }^{7}$ Kurzman, C. "Liberal Islam not a contradiction in terms", ISIM Newsletter, 2/99, 41.

${ }^{8}$ Renaissance.
} 


\section{Central Asian Sufi Governance Networks (14-19 Century)}

One of the key concepts that mirrors historical relationships of Islam and liberal democratic paradigms in Central Asia is Muslim governance networks. Sorensen and Torfing (2005) defined "governance network" as "horizontal articulation of interdependent, operationally autonomous actors who interact through negotiations in a normative framework, that to a certain extent is self-regulating and contributes to the production of public purpose within or across particular policy areas". Governance networks and communal ideologies in Central Asia incarnated decentralized system and influenced the complexity of ways Islam operated and evolved in the region. Here, the evolution of Islam did not occur through monoreligious trend and linear progression via centralized system with communities, branching the mosaic of highly syncretic and distinct cults, deities, saints, orders, and ideas. Communities consolidated the protection of private property and run their own communal funds and trusts. They effectively transmitted wealth across generations through the creation of the charitable foundation, the waqf, which operated independently from the state. They managed personal status issues, like marriage, death, and inheritance. The result was a flourishing civil society, which had become a central fact in the life of the Muslim societies in Central Asia.

For centuries, Sufis were at the heart of these evolving phenomena. Understanding tremendous historical role Sufi communities have played in the formation of Islam in Kazakhstan the authorities are currently attempting to legalize Sufism by placing it under the umbrella of the Hanafi Project. Which is easier said than done in such a futile manner that tend to ignore the historical, social, and political realities of the region. Sufis in Central Asia have always been largely autonomous and ideologically distinctive from the ortodox Hanafi clergy. Armstrong (2002) saw in Sufism a reaction against the growth of jurisprudence or Sunni mainstream schools of law, which seemed to some Muslims to be reducing Islam to a set of purely exterior rules.

In the teachings of the Yasawia order, which is attributed to the famous Central Asian Sufi Khoja Ahmad Yasawi, one would find a deep synthesis of Arab and Turkic cultures, Tengrianism, and Islam. Yasawia order has preserved the elements of Tengrianism as a symbol of the philosophy of life of the Turks. ${ }^{9}$ Some experts believe that Sufism preserved the basic ideas and rites of shamanism, where the state of ecstasy acts as a way of communicating with the other world, while the personalities of the shaman and the Sufi are so merged that shamans are included in the ranks of Muslim saints (Orynbekov, 2005). Yasawi made the city of Yasi into the major centre of Islamic learning for the Kazakh Steppe. ${ }^{10}$ His shrine was a site of strong spiritual and historic importance during the period of the Kazakh khanate, especially for the khans of the Middle Horde, because burial there was viewed as interment in sacred ground (Olcott, 2007). Yasawia order performed a complex function of transmitting pre-Islamic folk traditions, values, and ideological orientations aligning them to the dominant Islamic culture.

However, it was political dimension of Sufism that played a fateful role in the history of Central Asia. Sufi leaders helped define relations between the ruler and the ruled during the time of Timurid rule in 14-16 century. They were a source of legitimization for the rulers of the 18 century khanates in the region as well as a source of mobilizing protest during the last decades of Russian colonial rule (Olcott, 2007). Sufism was the incarnation of pre-colonial Islam, which considered itself a political subject, rather than the object acting as agent in a

\footnotetext{
9 Ayupov, N. Tengrianism as an open worldview. Author's abstract. Doctoral thesis (Almaty, 2004), 278-279.

${ }^{10}$ Basri, H. "Chapter 7: Islamic Culture in Turkish Areas. The Straight Path: Islam Interpreted by Muslims", ed. K. Morgan, The Ronald Press

//https://web.archive.org/web/20130411091600/http://www.religion-online.org/showchapter.asp?title=1656\&C=1643

Company:
} 
series of complex political, social, and cultural transformations.

Naqshbandiya without doubt has been the dominant Sufi brotherhood in Central Asia. Effective intercommunal relations, political, religious, and cultural autonomy developed by Naqshbandi sheikhs led to serious suspicions on the rulers' side. For example, during the meeting of Baha ud-din Naqshband with Malik Husain, the ruler of Herat, the latter began questioning the shaykh about his dervish (whether it was hereditary or not), his practice of zikr (whether he practiced loud zikr), sama' (musical ceremonies), and halvat (hermitary). Identification with institutional Sufism spoke of its impact on communal life and was perceived by the rulers as a threat to centralized political power, which complicated the relationships of Sufi shaykhs with the rulers. In response to hostility from the political authorities, Naqshbandia Hajjagan tried to appeal to several types of legitimizing principles that fluctuate from hereditary continuity, with its strict discipline and spirituality, to "silsila" ties that later became decisive for most Sufi communities (Hismatullin, 2001) and group solidarity. Naqshbandiya solidarity was always central for the brotherhood and was even higher than the bonds of Islam. Maulana Muhammad-Qazi, one of the main disciples of the prominent Sufi leader Khoja Akhrar quoted his teacher: "If I learned about the kafir in China, who speak highly of the outstanding (shaikhs) of this ta'if and their words, I would enter into his company without hesitation and without condemning him for being a kafir" (Hismatullin, 2001). These legitimizing principles have always played significant role in the competitive political struggle between the Sufi groups and the authorities in Central Asia.

Principles of communal self-governance applied by Naqshbandis were among many liberal elements that could be found in the history of Islam in Central Asia. Naqshbandis have ideologically shifted from such a traditional element of political life in Central Asia as "hereditary transfer of power". Their sources are full of derogatory and outlawing references to the shaykhs of Mirasi, mostly linked to Yasawia tradition, who were "trading in their father's shops" (Hismatullin, 2001). Among the fiercest shaykhs, Naqshbandiyya was Maulana Chusti, who had a stake in defining political affairs in the Ferghana Valley and Samarkand in 16th century. Chusti and his followers were hostile to the Shaikhs of Kubraviya and other rival Sufi groups intensely antipathizing the "hereditary shaykhs". One such "hereditary rival" was a charismatic shaykh Abd al-Qadir Turbati, who came with his supporters to Maulana Chusti to win over him. Instead, he was struck by a plague and soon "went to rest" at the grave of his ancestors (Hismatullin, 2001). Chusti himself broke with the principle of hereditary succession by refusing to follow in the footsteps of his father Mawlana Fathallah and joining Yasaviyya in favor of Naqshbandiya Khojjagan (Hismatullin, 2001).

Members of the Sufi orders had individual responsibilities towards their communities (quasi-states), but at the same time, they had freedom in political and ideological self-identification. The change in political views and preferences could at times involve not only individual shaykhs or members of the order, but the whole groups or communities. A vivid example of it is conversion of Khwarazm Yasavia community into Nashbandiya ideology in the early 17th century. Tokum Shaykh Khivaki of Yasavia order brought his 400 murids to the Shaykh of Naqshbandiyya and thereby "transferred" them to new brotherhood (Hismatullin, 2001). Here, we observe a mature Sufi shaykh with a fair number of followers passing on to another shaykh, which simultaneously indicate a collective shift and the degree of individual freedoms in the community.

All modern Naqshbandiya sheikhs in Central Asia begin the chain of their spiritual succession with Khoja Ahrar. Khoja Ahrar's religious justification for politicization of the brotherhood's activity was clear: “One should go to the rulers having raised the religion of the prophets to its limits, so that their throne and crown appeared insignificant compared to the eminence of the faith". He was highly critical of elevating adat law 
(customary law) to be the law of the state, superseding Islamic laws. He was also a strong critic of the ruling elite that imposed additional taxes—secular taxes not based on the Sharia—on the people. Khoja Ahrar's biographers suggest that in his relations with rulers he most often used the technique of pacification from the position of force, supported by his own economic might and the might of his supporters as well as his authority as a spiritual leader (Olcott, 2007). Khoja Ahrar also introduced a new ethical norm that stipulated that the sheikh and members of the brotherhood could and should be wealthy although he warned that they should have "their hearts not tied to their wealth". This peculiar capitalism with an ethical twist gave impetus to the economic activity of the brotherhood. From then on, many sheikhs of the brotherhood were among the wealthiest people of Transoxiana (Olcott, 2007).

\section{Social Contract of the Kazakh Hordes (16-17 Century)}

One cannot underestimate the effect of the social contract theory on political reforms in Europe, which resulted in successful transition of most countries of the region to liberal democracies. Social contract argued against the idea that monarchs were divinely empowered to legislate, asserting this right only to the people, who are sovereign and have that all-powerful right. In other words, it enshrined a separation of powers into different branches of government, the rule of law in everyday life, the equal protection of human rights, civil liberties, and political freedom for all people. Appealing to social contract Jean-Jacques Rousseau concluded that force does not create right and people are obliged to obey only legitimate powers ${ }^{11}$-a power that is of people's own free choice. Likewise, the ability to coerce is not a legitimate power, and there is no rightful duty to submit to it. ${ }^{12}$

Elements of the social contract could be found in the formation and the everyday life of the Kazakh hordes of the 16-17 century, which were federations or unions of self-governed tribes. They represented an extension of the temporary military unions formed by both Turk and Mongol tribes to make their lands more secure in the absence of strong central authority. The hordes gradually evolved into three stable unions with reasonably well-defined and stable territories under their control. When the Kazakh khanate began to break up at the beginning of the 18th century, the khan of each horde assumed the powers of sovereign ruler in his own territory, including the right to negotiate treaties with foreign power (Olcott, 1987). This was possible due to a clear-cut social contract between the centralized power of khans and local self-government of tribes, which suggested separation of powers, the rule of law in everyday life and the equal protection of rights, liberties, and political freedom for the people.

An aristocracy of khans and sultans existed upon a clan-based authority system. The Kazakhs had several great families that were divided among several auls that migrated together and generally grazed their animals on adjoining pastureland. Each aul had an elder, usually referred to as an aksakal (white beard), who was charged with the protection of his people. The elders met to choose a bii (judge and administrator) to represent the family in negotiations with other families, and to mediate internal disputes, regulate the migration and allocate pastureland. The office of bii was not hereditary and could be shifted if the elders so chose (Olcott, 1987). The Kazakhs had a dual authority structure which was, in fact, a coalition of self-governed entities-clans. It is here, in the inter-clan relationships and the relationships between clans and central authorities, that the social contract could be traced.

\footnotetext{
${ }^{11}$ Rousseau, J. “Social Contract \& Discourses”, New York: E. P. Dutton \& Co, 1913: http://www.bartleby.com/168/103.html 12 Ibid.
} 
The biis met to choose the sultans, who typically functioned as sub-khans ruling over particular territory and governing relations between clans, as well as to choose the khan, who governed the entire horde. Sometimes semi-autonomous territories existed within a horde, ruled by lesser khans who had sworn loyalty to the khan of the horde. To become khan an individual had to prove his own competence, ruling families were often eclisped by new claimants. Olcott rightly indicates that the Kazakhs adopted their system of princely rule from the Mongols. Membership in the Kazakh aristocracy (the white bone-ak suiuk) was restricted to individuals who at least in theory could trace their descent to Chingis Khan. By the end of 18th century, the White Bone had expanded to include hojas and descendants of the caliph. The general population of Kazakhs was known as black bone (kara suiuk), from which group the majority of Kazakh biis and aul leaders were chosen; they were eligible as well to serve as khans or sultans (Olcott, 1987).

Batirs (warriors) were invited to migrate with the retinues of sultans and khans, and they were often elected themselves to be khans. Olcott points out quite rightly on the check on the monopoly on political and military power of the khan. Although the khans functioned primarily as military leaders, the Kazakhs did not maintain standing armies. Instead, they depended on the lesser khans, sultans, and biis, all of whom raised and commanded their own armies from the populations that they governed. Each family accepted the obligation to provide one warrior to its particular bii or elder. These elders, however, were under no compulsion to lend these warriors to the khan, who thus was compelled to win the support of lesser authorities for any campaigns in which he might wish to engage. By the end of 18th century, the term bii had come to mean judge. Each bii had his own court, which he supported by collecting ten percent of all fines levied (Olcott, 1987). Within the larger Kazakh community, the clan leaders and elders had far more influence than the Khan. They allocated lands to the auls and families, they had control of the warriors, and unlike the khan, they had an unquestioned right of taxation as their right to part of each family's herd (Olcott, 1987). Thus, the early Kazakh state bears the mark of military democracy with the political authority of the khan being an extension of his military prowess.

The tribes acted as political institutions protecting ordinary folks from the tyranny of the authorities. No khan could, without reason, punish or kill a member of any Kazakh tribe, since the latter was under protection of his tribe members-distant and close relatives. Sabitov cites an example of Zhiembet-zhirau from the Tana tribe, who threatened to raise his tribe against Ishim Khan because of his brother. Even the Kazakh riots against the policy of the Russian Empire were, for the most part, the rise and attempts of particular tribes to defend their tribal lands. ${ }^{13}$

The steppe democracy could not pretend to fully reproduce the concept of contemporary liberal democracy for it is hardly possible. The birth of a liberal democracy was a product of a number of historical accidents and it could not be emulated easily. It is rather a target and an ideal type. However, the "steppe democracy" did contain certain important elements of the contemporary democratic mosaic, which proves that Muslims of Central Asia had its own history of liberal democratic development and thus authoritarian trend is not something culturally predetermined in the region.

\section{Multiculturalism and the "Folk Islam"}

The term "multicultural" is often used in contemporary political discourse and political philosophy in the context of Western liberal democratic societies. Proponents of multiculturalism reject the ideal of the "melting

13 Sabitov, Z. "Steppe democracy" and the "Elections in the great steppe", Vlast online magazine: https://vlast.kz/avtory/15340-stepnaa-demokratia-i-vybory-v-velikoj-stepi.html 
pot" in which members of minority groups are expected to assimilate into the dominant culture in favor of an ideal in which members of minority groups can maintain their distinctive collective identities and practices (Stanford Encyclopedia of Philosophy, 2016). According to the dominant view on multiculturalism, it is a liberal theory that blends the liberal values of autonomy and equality with an argument about the value of cultural membership. Cultures are instrumentally valuable to individuals: Cultural membership is an important condition of personal autonomy and plays an important role in people's self-identity. This means there is a deep connection between a person's self-respect and the respect accorded to the cultural group of which he is a part (Stanford Encyclopedia of Philosophy, 2016). In other words, collective identity is about attachment to particular culture that must be secured to serve as a meaningful context of choice and a basis of self-respect.

Continuous interaction between different cultures and communities in Central Asia preceded creation and decline of states, unleashing of wars, and dissemination of ideologies. One of the traditional forms of cultural diversity in Central Asia was syncretism, which played out both in intra- and inter- group dynamics. It has not only brought to life numerous authentic religious forms that dominated over any monoreligious trend, but also had a profound effect on the life of Central Asians, transcending their culture and society. In fact, syncretism goes to the heart of the modern identity of the region and its continuities are anchored in many aspects of everyday life-customs, behaviors, and traditions. Identification with ethnicity, religion, and culture still persists alongside loyalties to newly created nations and states.

Religiosity of Muslims in Central Asia was mainly expressed through observing the rules of everyday or folk Islam. Folk Islam was characterized by a mixture of native animistic beliefs with Islamic traditions in the popular consciousness. These practices and beliefs rely upon traditional magic and rituals that call upon the supernatural world. Folk Islam appeared to be more tangible for the grassroots communities rather than formal and complicated doctrines of the orthodox Islam, which was comprehensible mostly to ulama who possessed religious education.

Archaic beliefs were particularly strong among Kazakh nomads. This fusion of the "normative" Islam with the local ethnographic substrate has formed a phenomenon of the "steppe Islam" or folk Kazakh Islam. Levshin, depicting the life in the nomad steppes in the beginning of the 19th century, had indicated that the Kazakhs

in general had a notion of the highest being who created the world, but some worshipped him according to the laws of the Quran, others mixed the teachings of Islam with the remnants of ancient idolatry, the third believed that apart from the deity of the good, who cared about the happiness of people and whom they called "Kudai", there is an evil spirit, or Shaitan, the source of evil. (Levshin, 1996, p. 313).

The 19 century "Tobolsk Metropolitan Gazette" conclude that "although Kirghiz converted to Mohammedanism in ancient times, they still retain a large number of pagan superstitions. They recognize God, but they also believe that there are two spirits in the world: good and evil (Shaitan), that the souls of the deceased descend with the stars, that every day is under the protection of a special star, happy, or unhappy, which is why the days themselves are successful or unsuccessful"14. The Kazakhs have long preserved the religious rites of their pre-Islamic ancestors. Adapting religion to ethnic culture, the official and unofficial religious establishment absorbed many local cults that shaped religious consciousness of the people giving it syncretic and polystructural character (Toleubaev, 1972).

14 "On the Kazakhs and Kirghiz who inhabit the Akmola and Semipalatinsk regions", Tobolsk Metropolitan Gazette (Omsk, 1892), 77. 
The fire cult is one of the most important Kazakh cults. It can be traced among the inhabitants of medieval cities of Kazakhstan, as evidenced by the archaeological excavations. The Kazakhs linked fire with birth, growth, and life itself. Fire was personified by a female figure, Ot-ana (the Mother of Fire). Ot-ana was believed to be the mother of all people. Fire was associated with clan and family shrines. It was the patron of dwellings and placed in the temple of houses. Fire defended the family against all evils and brought wealth and happiness. Family prayers and sacrifices were performed to Ot-ana to ensure familial health and wealth. Appeals to fire for assistance and protection is the Kazakh tradition extending from ancient times to the present day (Nurgaliyeva, Tastaeva, \& Baibulsinova, 2017).

The idea of the ancient deity of Tengri gradually became identified with Allah. The terms "tangri" (sky), "kok tangri" (blue sky), and "tangri-daai" (God) are often found in the monuments of ancient Turkic writing. Almost always, along with the word "tengri" the Turks use word "hodai" (kudai), which means "God" (Valeev, 1980). The cult of the sun, moon, and stars was preserved in some rituals. Secondary deities and especially those containing images: Idols of the gods of the earth were completely forgotten, most probably due to persecution by Muslims at the time of the appearance of Islam (Valikhanov, 1985). Veneration of the deceased ancestors occupied an important place in the nomadic culture of Central Asia. The Kazakhs had a belief: If the funeral of the deceased accompanied by festivities is not performed, he will have to starve and suffer, and the house of a son who has not fulfilled his duty towards the father will suffer illness and poverty. If a misfortune occurs with the Kirghiz, he says: "Aruakh urdi, which means that the spirit of the dead ancestors beat him" (Slovohotov, 1905).

Gradually, the cult of ancestors in Central Asian became inseparable from Islam. Among characteristics of Islam, Kazakhstan is the presence of a large number of sacred sites (mazars) directly linked to myths, rituals and religious pilgrimage. Tying shawls or pieces of cloth on the graveside fence is the practice pilgrims engage in when they do not know prayers from the Quran. Besides mosque attendance, pilgirmages are one of the most visible manifestations of popular interest in Islam and are a considerable financial source for religious communities (Abramson \& Karimov, 2007).

Zoroastrian holiday of Nau Ruz (Navruz) (literally "New Day"), an annual celebration of the vernal (spring) equinox, the day on which the amount of darkness and sunlight are equal as the world emerges from the cold slumber of winter and awakens to the approaching summer, is perhaps the most notable popular ancient celebration in Central Asia. Special dishes are carefully prepared (sumalak for women and khalim for men), and children are entertained with traditional games, competitions, and pageantry. While Nau Ruz has no foundation in Islamic theology, its annual occurrence is much anticipated in modern Central Asia (Levi, 2007). Thus, Zoroastrian cultural heritage of Central Asia remains the ancient Persian's most apparent legacy in the region, and it has proven to be extraordinarily persistent among the Turk Muslims of the region.

\section{Conclusion}

Throughout history, the liberal patterns in the Muslim states and societies of Central Asia were confronted by different forms of authoritarianism that oppressed diversity, denied freedom of expression, demanded absolute obedience, and used hard repression against individual freedom and liberties. But as much as this epic struggle led to continuous setbacks of democratization and freethinking, it has determined the identity and cultural self that made Muslims of Central Asia accept liberal ideas.

In many stances, Islam in Central Asia experienced modernity in the same way as Christianity in the West. 
Liberalism grew out of the bloody medieval religious wars in Europe, which resulted in recognition that the only way to stability and normal life was a society, in which people put aside contestations over ultimate ends and agree to live under a framework of law. This universal principle of the modern liberal democracy has potential for reconciliation with Islamic tradition in Central Asia. As in Western Europe, feudalism in Central Asia held constant resistance to centralizing and modernizing monarchies in the medieval time, which did not leave a legacy of strong state power in the region, but rather a strong civil society not necessarily dependent on state authority. Muslim communities being self-reliant and resourceful sought to preserve the ability to organize themselves privately and spontaneously, to work together at local levels, and to take responsibility for their own lives. Thus, living in multifaith, multiethnic, and multilingual societies has always been part of the experience of Muslims in Central Asia. This suggests that Islamic identity of the region has been determined by multicultural rather than a monoreligious (mono-madhab) trend, which makes groundless the state's argument about historical predestination of a single form of religiosity.

Current attempts of the states of the region to replace "natural Islam" with the secular nationalist ideology will only galvanize the social unrest and lead to radicalization and politicization of Islam. The Kazakhstan's Hanafi Project is an artificial construct that has doubtful peaceful prospects as it contradicts both the historical evolution of Islam in Central Asia and the Muslims' understanding of Islam, as even the classical Hanafism was shaped differently in various ethnic communities of the region and informed different ethnic traditions. Those who promote incorporation of the Hanafi Project into the everyday life of Muslims of Kazakhstan have to revisit the democratic values and keep an open mind in understanding what may cause drawbacks in the acceptance and the establishment of an ideology that is based on compulsory principles.

The Muslim rulers in the history of Central Asia were usually schooled in Islam from childhood and had social bonds to the religion, something contemporary leaders does not possess. Knowledge of the religion that declined over decades of Soviet rule is most noticeable among the post-communist ruling elite of the region that still harbor suspicion of deeply pious Muslims. Nevertheless, this did not stop them from emphasizing their commitment to the Muslim faith, which ultimately helped to improve their own status in the eyes of the population. Despite drastic geopolitical changes and the global movement towards democracy and liberalization, the religious policies in the most of the Central Asian states do not differ much from the Soviet ones. State control over religion today is still clearly secular, as it was during the Soviet era: Strict hierarchical structure of the Spiritual Administration of the Muslims that oversaw the Islamic activities are still retained, religion is not allowed into the public sphere, the state appoint imams on a unilateral basis and passed laws restricting the activities of religious groups.

Secular leaders and representatives of the "educated elite" often label Islam despotic, backward and contradictory to progress. However, this dichotomy of Islam and despotism in the popular consciousness of the region does not correspond to historical realities. It is no mere chance that this vision was consistently imposed, particularly through the state propaganda, by the Soviets that saw the threat in Islam. Today, Islamophobia is still flourishing at the highest state level in Central Asia, despite the fact that the recent anthropological studies convincingly prove that Soviet influence has made the Central Asian Muslims highly immune to the influence of the radical religious ideas. Most Muslims support the secular system, or at least are ambivalent towards it, and do not seek to destroy it (Lemon, 2017).

In Kazakhstan, where the state-sanctioned form of Islam has to ultimately become the national identity, any distinct manifestations of religion are viewed as "foreign and alien". Through years of independence, the 
interference of the state into private and family life of believers had reached unprecedented levels. Secular government through its network of "universal experts" and puppet religious organizations warn citizens about "foreign influence" and what "lead people to radicalism": wearing hijabs, rolling up trousers above the ankles, growing beards, performing regular prayers differently from the official behavior regulations (Corley, 2017), reading any religious literature un-censored by the state and so on. The explicit result of these policies is that many stopped attending mosques and began to obtain religious knowledge via Internet. A small group of wise statesmen and experts develop and impose religious ideology and dress code on people according to own personal ideas of right and wrong, decide what the national traditions are and what is not.

There are many intolerant societies around the world, but in the end because of the de-facto diversity a way to instituonalized system that allows different people to live together peacefully should be worked through. The religious situation reflects a state's level of civilization: despotic, backward, democratic, or progressive. The true faith comes from awareness and non-compulsion, so instead of censoring the religious life the state should rather create conditions by its openness and liberal policies to ensure the victory of the enlightened Islam. There is a vital fact about Islam, which any wise statesmen would never ignore: Islam as an actor has deep historical and ideological roots in the popular consciousness of the region, much older than any of the contemporary nation-states could possess. Pandora's Box is better kept closed: The tectonic clash of competing legitimacies can have serious implications for Kazakhstan and the whole region.

In heterogonous Kazakhstan, Muslim communities can play a vital role in building strong civil society and inspiring effective democratic institutions through development of community governance networks, which constitute grassroots level for democracy in culturally fragmented and multi-layered state. Just as historically Islam created various cultures through absorbing elements of pre-Islamic beliefs and traditions, today it is vibrant and dynamic potential can become the basis for the advancement of progressive ideas of democracy. Today, the fate gives Kazakhstan another chance for democratic transit on the basis of evolutionary rather than revolutionary models. For the state religious politics, this should mean the liberal paradigm of Islam to be at the heart of decision-making; for the believers, true liberalisation of the religious life.

\section{References}

Abramson, D., \& Karimov, E. (2007). Sacred sites, profane ideologies: Religious pilgrimage and the Uzbek State. In J. Sahadeo and R. Zanca (Eds.), Everyday life in Central Asia: Past and present (p. 320). Bloomington: Indiana University Press.

Amire, E. (2014). Islam ne prizivayet $k$ vrazhde (Islam does not call for hostility). Retrieved from http://www.muftyat.kz/ru/article/235

Armstrong, K. (2002). Islam: A short history. New York, N.Y.: The Modern Library.

Baigarin, M. (2011). V Kazakhstane naschityvaetsia 2300 mechetei (There are 2300 mosques in Kazakhstan). Retrieved October 8, 2015, from http://www.inform.kz/rus/article/2397800 (in Russian)

Beissembayev, S. (2016). Religious extremism in Kazakhstan: From criminal networks to Jihad. The Central Asia Fellowhip Papers, No. 15, Febuary, 2016, p. 3.

Bourdieu, P. (1977). An outline of a theory of practice. Cambridge: Cambridge University Press.

Corley, F. (2017). Kazakhstan: Fined for praying "Ameen" in Mosque. Retrieved from http://www.forum18.org/archive.php?article_id=2267

Dahl, R. (1956). A preface to democratic theory. Chicago: University of Chicago Press.

Dahl, R. (1963). Who governs? Democracy and power in an American city. New Haven: Yale University Press.

Forde, S. (2011). John Locke and the natural law and natural rights tradition. Retrieved from http://www.nlnrac.org/earlymodern/locke

Fukuyama, F. (1992). The end of history and the last man. New York, N.Y.: Macmillan. 
Hays, J. (2016). Religion and Islam in Kazakhstan. Retrieved from http://factsanddetails.com/central-asia/Kazakhstan/sub8_4a/entry-4637.html

Hismatullin, A. (Ed.). (2001). Sufism in Central Asia: Foreign research. St. Petersburg: State University.

Jenkinson, C. (2004). Becoming Jefferson's people. Reno: Marmarth Press.

Kazmi, Z. (2015). Beyond liberal Islam. Retrieved from https://aeon.co/essays/is-it-time-to-look-beyond-the-idea-of-liberal-islam Krouse, R. (1982, Spring). Polyarchy \& participation: The changing democratic theory of Robert Dahl. Polity, 14(3), 443.

Kurzman, C. (1999). Liberal Islam: Prospects and challenges. Retrieved from http://www.rubincenter.org/1999/09/kurzman-1999-09-02/

Lemon, E. (2017). Islam, gosudarstvennost'i bezopasnost'v postsovetskoi Tsentralnoi Azii (Islam, statehood and security in the post-Soviet Central Asia). Retrieved from http://russian.eurasianet.org/node/64896

Levi, S. (2007). Turks and Tajiks in Central Asian history. In J. Sahadeo and R. Zanca (Eds.), Everyday life in Central Asia: Past and present (pp. 17-18). Bloomington: Indiana University Press.

Levshin, A. (1832). Opisaniye kirgiz-kazachikh ili kirgiz-kaysakskikh ord i stepey (Description of Kirghiz-Cossack or Kirghiz-Kaisak hordes and steppes). Saint-Petersburg: Etnograficheskiye Izvestiya.

Levshin, A. (1996). Description of the Kirghiz-Cossacks or the Kirgiz kaisaks, hordes and steppes. Almaty: Sanat.

Mondal, A. (2003, January). Liberal Islam? Retrieved from https://reader.exacteditions.com/issues/4 9481/page/30

Mosca, G. (1939). The ruling class. (A. F. Livingstone, Trans.). New York, N.Y.: McGraw Hill.

Nurgaliyeva, A., Tastaeva, Z., \& Baibulsinova, A. (2017). The fire cult and Islam in the Kazakh system of beliefs. Trames, 21(71/66), 156.

Olcott, M. (1987). The Kazakhs. Stanford, California: Hoover Institution Press.

Olcott, M. (2007). Sufism in Central Asia: A force for moderation or a cause of politicization? Washington: Carnegie Endowment for International Peace.

Orynbekov, M. (2005). Genesis of religiosity in Kazakhstan. Almaty: Daik-Press.

Radio Free Europe/Free Liberty. (2016). Kazakhstan reiterates school hijab ban. Retrieved from https://www.rferl.org/a/kazakhstan-bans-hijab-in-schools/28065025.html

Ro'i, Y., \& Wainer, A. (2009). Muslim identity and Islamic practice in post-Soviet Central Asia. Central Asian Survey, 28(3), 303-322.

Slovohotov, L. (1905). The people's court of the common law of the Kirghiz of the little horde. Proceedings of The Orenburg Scientific Archive Commission (Issue 15, p. 34). Orenburg: Turgai Regional Printing House.

Sorensen, E., \& Torfing, J. (2005). Network governance and post-liberal democracy. Administrative Theory \& Praxis, 27(2), 197-237.

Stanford Encyclopedia of Philosophy. (2016, August). Multiculturalism. Retrieved from https://plato.stanford.edu/entries/multiculturalism/

Stanford Encyclopedia of Philosophy. (2016, January). Locke's political philosophy. Retrieved from https://plato.stanford.edu/entries/locke-political/

Toguzbayev, К. (2011). Лидеры казахских суфиев отправлены в тюрьму на долгие годы (The leaders of the Kazakh Sufis have been sent to jail for many years). Retrieved from https://rus.azattyq.org/a/kazakh_sufi_ismatulla_abdigappar_sajat_ibragimov_verdict/24364804.html

Toleubaev, T. (1972). Relics of pre-Islamic beliefs in the family rites of the Kazakhs (19th and early 20th centuries). Alma-Ata: Gylym.

U.S. History Online Textbook. (2017). Jeffersonian ideology. Retrieved from http://www.ushistory.org/us/20b.asp

Urnaliyev, S. (2017). Школьнии в платках не пускают на занятия в Уральске (Schoolgirls in hijab are not allowed to attend classes in Uralsk). Retrieved from https://rus.azattyq.org/a/uralsk-shkola-nedopusk-platki/28775296.html

Valeev, F. (1980). West Siberian Tartars in the second half of the 19th and early 20th centuries (historical and ethnographic essays). Kazan: The Tartar Publishing House.

Valikhanov, C. (1985). Traces of shamanism among the Kirghiz (Vol. 4). Alma-Ata: Science. 